\title{
Homologous nonallelic recombinations between the iduronate-sulfatase gene and pseudogene cause various intragenic deletions and inversions in patients with mucopolysaccharidosis type II
}

Susanna Bunge ${ }^{1}$, M ichaela R athmann ${ }^{1}$, Cordula Steglich ${ }^{1}$, M arie-L ouise B ondeson ${ }^{2}$, A nna Tylki-Szymanska ${ }^{3}$, E wa Popowska ${ }^{4}$ and A ndreas $G$ al $^{1}$

${ }^{I}$ I nstitut für H umangenetik, U niversitäts-K rankenhaus E ppendorf, $\mathrm{H}$ amburg, G ermany

${ }^{2} B$ eijer L aboratory, D epartment of M edical G enetics, U ppsala U niversity, U ppsala, Sweden

${ }^{3} \mathrm{D}$ epartments of M etabolic D isease and ${ }^{4} \mathrm{G}$ enetics, Child $\mathrm{H}$ ealth Centre, Warsaw, Poland

\begin{abstract}
About $20 \%$ of patients with mucopolysaccharidosis type II (MPS II) have gross structural rearrangements involving the iduronate-sulfatase (IDS) gene in Xq27.3-q28. A nearby IDS pseudogene (IDS-2) promotes nonallelic recombination between highly homologous sequences. Here we describe major rearrangements due to gene/pseudogene recombination. In two unrelated patients, partial IDS gene deletions were found joining introns 3 and 7 of the IDS gene together with gene to pseudogene conversion in the area of breakpoints. In a third patient, a junction between intron 3 of IDS-2 and intron 7 of IDS was seen that was due to a deletion and inversion of the $5^{\prime}$ part of the gene. Characterisation of breakpoints in six patients with large inversions revealed that all recombinations of this type occurred in the same area of homology between IDS and IDS-2; they were molecularly balanced, and accompanied by gene conversions in most cases. Apart from diagnostic implications, such naturally occurring recombination 'hot spots' may allow some insight into general features of crossover events in mammals.
\end{abstract}

Keywords: MPS II; Hunter syndrome; IDS-2; pseudogene; inversion; deletion; recombination; gene conversion

\section{Introduction}

M ucopolysaccharidosis type II (MPS II, Hunter syndrome) is an $\mathrm{X}$-linked storage disorder caused by deficiency of the lysosomal enzyme iduronate-2-sulfatase (IDS). D ue to accumulation of partially degraded

Correspondence: Dr Susanna Bunge, Institut für Humangenetik, U niversitäts-K rankenhaus E ppendorf, Butenfeld 42 , 22529 H amburg, Germany. Tel: 49-40-4717-4597; Fax: 49-40-4717-5138; E mail: bunge@plexus.uke.uni-hamburg.de Received 27 November 1997; revised 23 February 1998; accepted 6 M arch 1998 dermatan and heparan sulfates patients present with hepatosplenomegaly, skeletal deformities, connective tissue abnormalities, and mental retardation. ${ }^{1}$ Since characterisation of the ID S CD NA and gene, ${ }^{2-4}$ diseasecausing mutations have been described for many unrelated patients. ${ }^{5,6}$

In more than $80 \%$ of patients with MPS II, impairment of enzyme function is caused by point mutations or deletions/insertions of less than 20 base-pairs. $^{5}$ A bout $20 \%$ of all patients have total or partial gene deletions or other major gene rearrangements. D etection of an ID S pseudogene (ID S-2 or ID S $\psi)^{7,8}$ located 
in inverted orientation $20 \mathrm{~kb}$ telomeric to the functional gene ${ }^{9}$ offers a likely explanation of complex mutational events by intrachromatid recombination between two highly homologous regions. ${ }^{10} \mathrm{~A}$ high frequency intragenic inversion has been reported in patients of different ethnic origin. ${ }^{11,12}$ In Southern analysis of $\mathrm{H}$ indlII digested genomic DNA, all cases presented with a characteristic and identical pattern consisting of two junction fragments of about 3.2 and $12.9 \mathrm{~kb}$. This finding was unexpected for MPS II, an X-linked disorder genetically lethal for males, as such traits usually show an extreme allelic heterogeneity with most of the mutations being 'private'.

We describe here determination of breakpoints in six unrelated patients with inversions and in three patients with partial deletions and show that, on the molecular level, the three latter rearrangements are different. A model is proposed of how gene/pseudogene interactions may lead to recurrent intragenic deletions.

\section{Materials and Methods}

Patients with complex rearrangements investigated in this study belong to a collective of more than 70 patients with M PS II from different E uropean countries among whom we have performed ID S gene mutation screening. Table 1 lists the patients analysed and their countries of origin. A II patients presented with the classical severe form of MPS II. Preliminary data on some of the patients were presented in previous studies (see Table 1).

DNA and RNA was extracted from whole blood samples or cultured skin fibroblasts according to standard procedures. Southern blots of $\mathrm{H}$ indlII and Stul digested genomic DNA were hybridised with the ID S CD NA as described. ${ }^{12}$ Construction of restriction maps and assignment of exons to Southern blot fragments was performed by using the published IDS gene and pseudogene sequences. ${ }^{9}$ RT-PCR amplification of IDS coding sequence from $\mathrm{mRNA}$ in four overlapping fragments was done as described. ${ }^{13} \mathrm{~A}$ schematic draw of RT-PCR fragments is given by $B$ unge et al. ${ }^{13} \mathrm{In}$ addition, primers in the 5'- and $3^{\prime}$-regions of the CDNA were combined to analyse transcripts with internal deletions. A mplification of exons was done with intron-specific primers as described previously. ${ }^{6,14}$ ID S exon 3-forward and exon 8-reverse primers were used to generate a $2.8 \mathrm{~kb}$ junction fragment that included both the proximal breakpoints of inversions and internal deletion breakpoints. Primers IDS62 and IDS63 (similar to 60033-F and 58740-B in ref. 15) were used to amplify a $1.3 \mathrm{~kb}$ gene intron 7-fragment, ID S64 and ID S65 (similar to $97690-\mathrm{F}$ and $98855 \mathrm{~B}$ in ref. 15) for a $1.3 \mathrm{~kb}$ IDS2-specific intron 7-fragment. Localisation of these primers is given in Figures 1 and 3. Primer pairs ID S62/IDS65 and ID S64/ID S63 produced amplicons containing the distal and proximal inversion breakpoints, respectively. A mplification products were purified with microcon 100 concentrators (A micon, Witten, Germany) and sequenced with the Dye Terminator cycle sequencing kit (Perkin Elmer, Weiterstadt,
Germany) on an ABI Prism ${ }^{-m}$ sequencer. To obtain the complete sequence of the 2.8 and $1.3 \mathrm{~kb}$ fragments, internal sequencing primers were used. Sequences were compared to the published IDS gene and pseudogene sequences. To analyse the second recombination breakpoint of patient 16 , the U niversal Genome Walker K it (Clontech, Heidelberg, Germany) was used. B riefly, genomic DNA of the patient was digested with different restriction enzymes and ligated to adaptor primers. U sing a combination of adaptor-specific and ID S gene-specific primers in a nested PCR, it was possible to characterise the sequence that follows gene intron 3 in patient 16 's genome.

\section{Results}

Characterisation of Partial Deletions/Complex Rearrangements

Table 1 summarises the genomic blot and PCR data on four patients with partial gene deletion.

In patient 9 (P9), all exons except 5 and 6 were detected by PCR, and the sequences corresponding to exons 5 and 6 were also absent in the CDNA. Both the Stul and $\mathrm{H}$ indlII restriction patterns of genomic DNA are consistent with deletion of exons 5 and 6 . A ttempts to amplify across the breakpoint with primers located upstream of exon 5 and downstream of exon 6 were unsuccessful. The absence of the pseudogene-specific $6.5 \mathrm{~kb} \mathrm{HindlII}$ band and presence of two novel (most likely) junction fragments is difficult to explain at the moment. The patient may carry two deletions. Inversion-specific PCR s did not result in any product, while IDS and IDS-2 intron 7-fragments of normal size were amplified from P9's DNA .

$U$ sing genomic $D N A$ of patients $P 1, J N$, and $P 16$, no amplification products were obtained for exons 4 to 7 , whilst exons $1,2,3,8$, and 9 were detectable and unaltered. A nalysis of CD NA revealed transcripts with internal deletions of exons 4 to 7 in patients $P 1$ and J N. The Stul hybridisation pattern of $\mathrm{P} 1$ and $J \mathrm{~N}$ was identical showing a junction fragment of about $2.7 \mathrm{~kb}$, while P16 had a junction fragment of $4.0 \mathrm{~kb}$. Similarly $\mathrm{H}$ indIII-patterns of $\mathrm{P} 1 / \mathrm{J} \mathrm{N}$ and $\mathrm{P} 16$ were also different. $\mathrm{U}$ nexpectedly, all three patients showed a $\mathrm{H}$ indlII junction fragment migrating like the $3.2 \mathrm{~kb}$ junction fragment of patients with inversions (see below). A Iso, genomic PCR with exon 3-forward and exon 8-reverse primers resulted in products similar in size to the distal junction fragment of inversion patients. These fragments were sequenced for all three cases (Figure 1). It turned out that two different types of rearrangements were present. In patients $\mathrm{P} 1$ and $\mathrm{JN}$, there is a junction between exons 3 and 8 of the IDS gene. The intron 
Table 1 R esults of PCR and genomic Southern blot analyses of 10 patients with major rearrangements of the IDS gene

\begin{tabular}{|c|c|c|c|c|c|c|c|c|}
\hline \multirow[b]{3}{*}{ Patient } & \multirow[b]{3}{*}{ Origin } & \multicolumn{4}{|l|}{ PCR } & & & \multirow[b]{3}{*}{ Reference } \\
\hline & & \multirow{2}{*}{$\begin{array}{l}\text { exons (amplified } \\
\text { from genomic } \\
\text { DNA) }\end{array}$} & \multirow[b]{2}{*}{$\mathrm{CDNA}^{2}$} & \multirow{2}{*}{$\begin{array}{l}\text { proximal } \\
\text { junction }\end{array}$} & \multirow{2}{*}{$\begin{array}{l}\text { distal } \\
\text { junction }\end{array}$} & \multicolumn{2}{|l|}{ genomic Southern blot ${ }^{1}$} & \\
\hline & & & & & & Stul digest ${ }^{3}$ & HindllI digest ${ }^{4}$ & \\
\hline P9 & PL & $\begin{array}{l}\text { no amplification } \\
\text { of exons } 5 \text { and } 6\end{array}$ & $\begin{array}{l}\text { 1.1: + } \\
\text { 1.2; 2; 3:- } \\
1.2 F, 3 R: \text { del ex } 5,6\end{array}$ & - & - & $\begin{array}{l}\text { missing: } \\
3.0(6), 4.4(4,5)\end{array}$ & $\begin{array}{l}\text { missing: } 4.5(4,5) 6.5 \text { (ps3), } \\
9.6(6,7, \text { part } 8) \\
\text { new: } 11.0,14.0\end{array}$ & this study \\
\hline P1 & $\mathrm{PL}$ & $\begin{array}{l}\text { no amplification } \\
\text { of exons 4-7 }\end{array}$ & $\begin{array}{l}\text { 1.1: }+ \\
\text { 1.2;2;3:- } \\
1.2 F, 3 R: \text { del ex 4-7 }\end{array}$ & + & - & $\begin{array}{l}\text { missing: } 3.0(6), 3.2(7) \\
3.4 \text { (part } 1,2,3), 4.4(4,5) \\
\text { new: } 2.7^{5}\end{array}$ & $\begin{array}{l}\text { missing: } 2.5(3), 4.5(4,5) \\
9.6(6,7, \text { part } 8) \\
\text { new: } 3.2\end{array}$ & this study \\
\hline$J N$ & DK & see P1 & see P1 & + & - & see P1 & see P1 & 12 , patient 1 ; this study \\
\hline P16 & $\mathrm{PL}$ & see P1 & $\begin{array}{l}1.1:+ \\
1.2 ; 2 ; 3:- \\
1.2 F / 3 R:-\end{array}$ & + & - & $\begin{array}{l}\text { missing6: } 3.0(6), 3.2(7) \\
\text { 3.4 (part 1, 2, 3), } 4.4(4,5) \\
\text { new: } 4.0\end{array}$ & $\begin{array}{l}\text { missing: } 2.5(3), 4.5(4,5) \\
6.5 \text { (ps3), } 9.6(6,7, \text { part } 8) \\
\text { new: } 3.2,12\end{array}$ & 16, HP16; this study \\
\hline P10 & $\mathrm{PL}$ & $\begin{array}{l}\text { all exons } \\
\text { amplified, normal }\end{array}$ & $\begin{array}{l}1.1 ; 1.2 ;+ \\
2 ; 3:-\end{array}$ & + & + & $\begin{array}{l}\text { unaltered compared to } \\
\text { controls }\end{array}$ & $\begin{array}{l}\text { missing: } 6.5 \text { (ps 3), } 9.6 \\
(6,7, \text { part } 8) \\
\text { new: } 3.2,12.9\end{array}$ & this study \\
\hline P11 & $\mathrm{PL}$ & see P10 & see P10 & + & + & see $\mathrm{P} 10$ & see P10 & this study \\
\hline P17 & $\mathrm{PL}$ & see P10 & see P10 & + & + & see $\mathrm{P} 10$ & see P10 & $\begin{array}{l}\text { this study; identical to } \\
\text { patient } \mathrm{V} \text { in } 15 ?\end{array}$ \\
\hline P21 & $\mathrm{PL}$ & see P10 & see P10 & + & + & see P10 & see P10 & $\begin{array}{l}\text { this study; identical to } \\
\text { patient IV in 15? }\end{array}$ \\
\hline BR & $\mathrm{DE}$ & see P10 & see P10 & + & + & see $\mathrm{P} 10$ & see P10 & 12 , patient 2 ; this study \\
\hline PF & $\mathrm{DE}$ & see P10 & see $\mathrm{P} 10$ & + & + & see $\mathrm{P} 10$ & see $\mathrm{P} 10$ & 6; this study \\
\hline
\end{tabular}




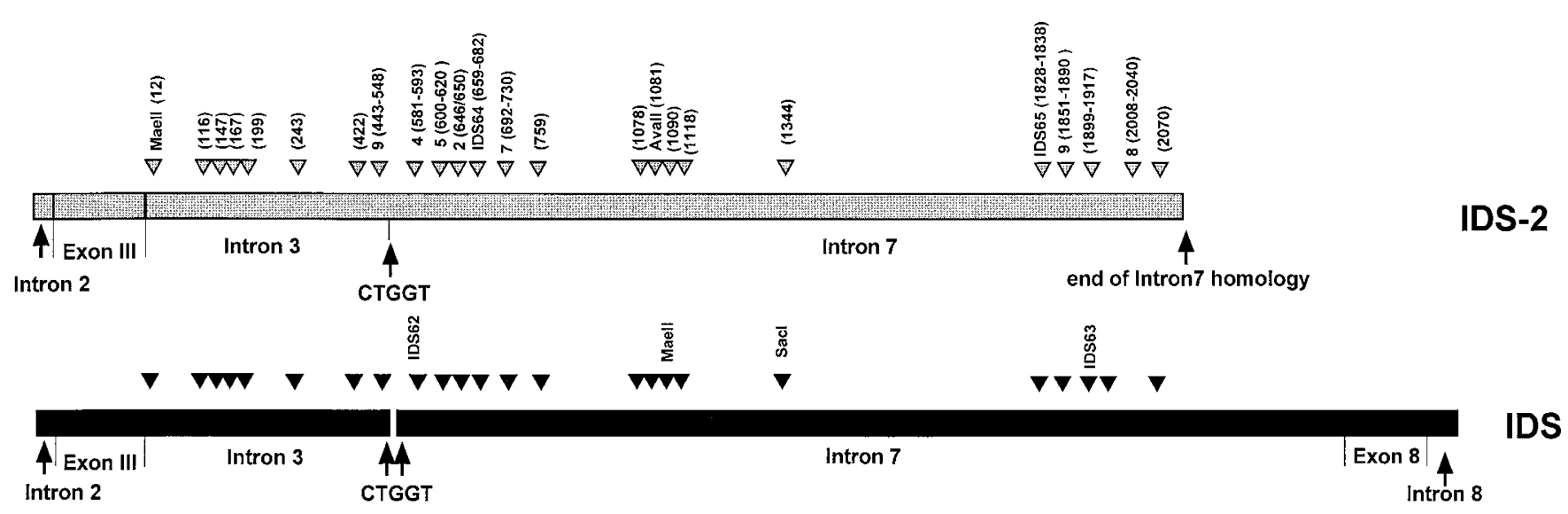

Figure 1 Schematic summary of IDS deletions/rearrangements. In the upper half, partial maps of IDS-2 (grey box) and ID S (black box) are given with positions of exons and introns marked below. CTGGT represents the overlap between intron 3- and intron 7-homologous sequences in ID S-2. Sequence and restriction site differences between gene and pseudogene are marked by triangles; positions of primers ID S62 to ID S65 are also indicated. The first nucleotide of intron 3 of ID S-2 is arbitrarily termed nucleotide 1. $\mathrm{N}$ ote that numbering is consistent only for the pseudogene, as intron 3 and intron 7 are linked only in ID S-2. A Iso, there are some insertions in IDS-2 when compared with the gene (after nts 660, 709 and 1833). Numbers before brackets indicate how many differences are found in a small area, numbers in brackets refer to corresponding nucleotides. In the lower section, deletion junction areas are given for patients $\mathrm{P} 1, \mathrm{~J}$, and $\mathrm{P} 16$, with regions containing possible breakpoints in white.

3/intron 7 deletion junction is similar to the intron 3/intron 7 connection present in wild-type IDS-2. Whereas the $5^{\prime}$ and $3^{\prime}$ ends of the intron junction are identical to the IDS gene sequence, the 922 (P1) or $669 \mathrm{bp}$ (J N) middle part is homologous to IDS-2 as evidenced by the presence of several pseudogenespecific sequence variants. A s one of the gene/pseudogene transition areas differs between JN and P1, their gene lesions represent independent mutational events. In JN and P1, no PCR product was seen with primers ID S62/65 or ID S62/63, whilst the IDS-2 intron 7 PCR (ID S64/65) produced a normal fragment. Presence of ID S-2 in these patients was suggested by pseudogenespecific bands in Southern blots and the fact that intron 3 PCR (without distinction between IDS and ID S-2) amplified fragments heterozygous for the $M$ aell site at position +12 after exon 3 , which differentiates between IDS and ID S-2 exon $3 .^{6}$

Patient P16 carries a different mutation, as there is a junction between pseudogene exon 3 and gene exon 8 . In this case, it was not possible to amplify the ID S-2 intron 7-region with primers ID S64/65. Exons 1 to 3 of the IDS gene should be present in correct orientation with respect to ID S promoter, as transcripts containing these exons were found in P16. A Iso, amplification products of exon 3 with primers not discriminating between gene and pseudogene were heterozygous in $M$ ael I restriction. The $\mathrm{G}$ enome Walker $\mathrm{K}$ it was used to characterise the second breakpoint. It turned out that exon 3 (gene) is followed by 1401 bp intron 3 sequence. The sequence continues with 17 nucleotides from intron 7 in inverted orientation (IV S7 + 1685 to +1669 ), although it is not possible to determine whether these nucleotides are of IDS or ID S-2 origin. A fter these nucleotides there is a direct link to a sequence normally located $28 \mathrm{~kb}$ distal of IDS (within 'gene $W^{\prime}$ ', see Timms et al) ${ }^{9}$. A $n$ inversion of the 5 ' part of IDS and another $28 \mathrm{~kb}$ deletion is probable. Figure 2 shows schematically how homologous sequences of gene and pseudogene could have paired forming a loop which contains exons 4 to 7. A H olliday recombination structure could have been resolved leading to an internal deletion with or without an additional inversion. 


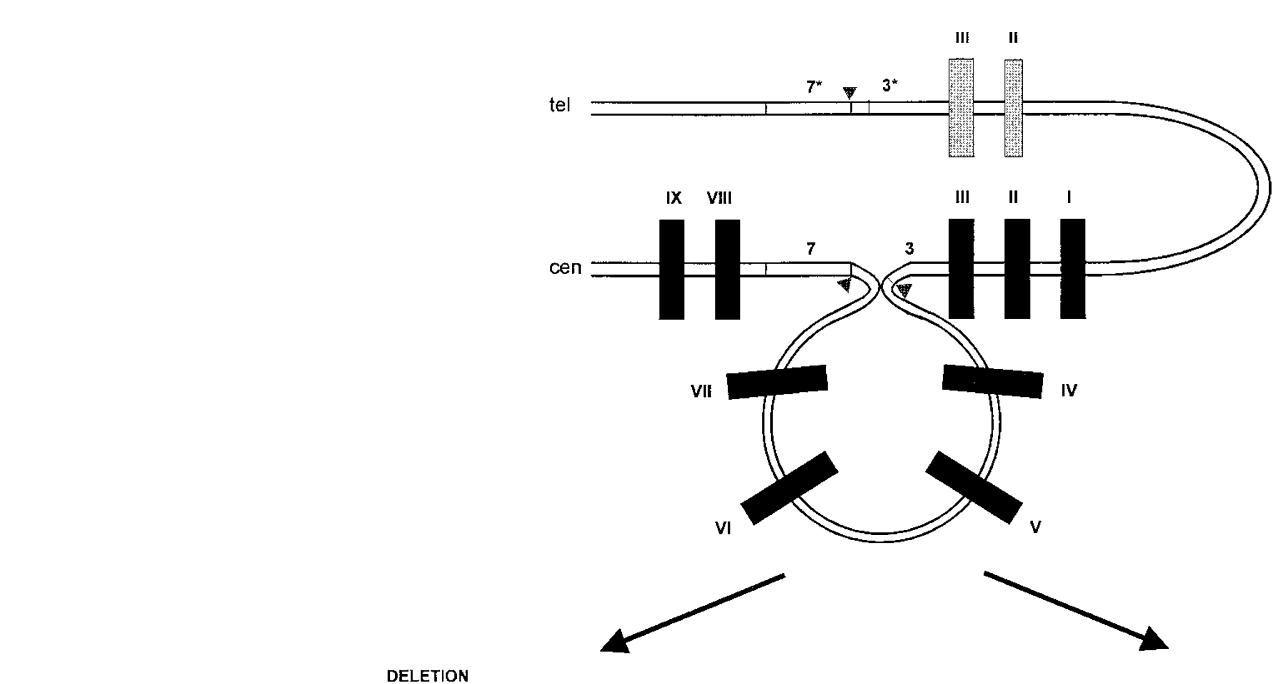

DELETION + INVERSION
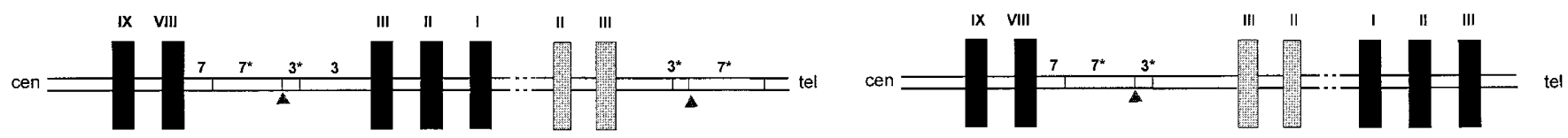

Figure $2 \mathrm{H}$ ypothetic model of intrachromosomal recombination leading to intragenic ID $S$ del etion. Exons are indicated with $\mathrm{R}$ oman numbers, introns are marked by A rabic numbers (asterisks indicate ID S-2 introns). G ene exons are shown as black boxes, ID S-2 exons as grey boxes. Triangles indicate the sequence CTG G T. 'D el etion' is the internal deletion present in patients J N and P 1; deletion and (putative) inversion was found in patient P 16.

\section{Characterisation of Inversions}

PCR fragments of normal size and sequence were obtained for all exons in patients P10, P11, P17, P21, $B R$, and $P F$, when genomic DNA was used as template. By RT-PCR, only the 5 ' half of the IDS transcript was detectable. In all six patients, the Stul pattern of genomic DNA was unaltered compared with controls, whereas two wild-type bands were missing in the $\mathrm{H}$ indlII blot but two novel bands occurred (Table 1 ). In these patients, no PCR product was obtained with primers ID S62/ID S63 or ID S64/ID S65. Primer combinations ID S62/ID S65 and ID S63/ID S64 which did not produce any PCR products in control DNA samples resulted in amplification of fragments of about $1.3 \mathrm{~kb}$ containing the distal and proximal inversion breakpoints in the DNA of the six patients. A Iso, with exon 3 forward primer and exon 8 reverse primer, junction products of about $2.8 \mathrm{~kb}$ were obtained.

The families of all four Polish patients, P10, P11, P17 and $\mathrm{P} 21$, with inversions originate from a small geographic area in the south-eastern part of the country (between Starachowice and L wów). Thus a common ancestor was suspected. H owever, whilst the mothers of three of the patients were carriers, that of P17 was not. To find out whether the inversion breakpoints are similar or different, distal and proximal junction fragments were sequenced. Figure 3 gives a schematic representation of the different junction fragments. Some of the patients share identical proximal or distal breakpoints, but only two of them (P10 and BR) are identical for both. A s P10 originates from Poland and $B R$ from $G$ ermany the two gene alterations are likely to be of independent origin. A t first glance, none of the inversion events can be explained by a simple reciprocal strand exchange. The P10/BR inversion could have resulted from such an event if the pseudogene involved in the rearrangement had harboured the gene-specific nucleotide at position 1090 (see Figure 3). Indeed, this IDS gene-specific polymorphism was found in IDS-2 of control persons. ${ }^{15}$ The recombination event in PF can be explained by an initial double-stranded break at any position between nucleotides 1344 and 1823 followed by invasion of single strands into the pseudogene homologous region, branch migration, and conversion of the gene part of the distal inversion area between 1078 and 1344 into pseudogene sequence. ${ }^{15}$ If patient P21's ancestor had harboured the gene-specific nucleotide 1090 polymorphism in his pseudogene, a pseudogene to gene conversion would be likely at least for nt 1344 in the distal junction area. Patient P11 shows the 


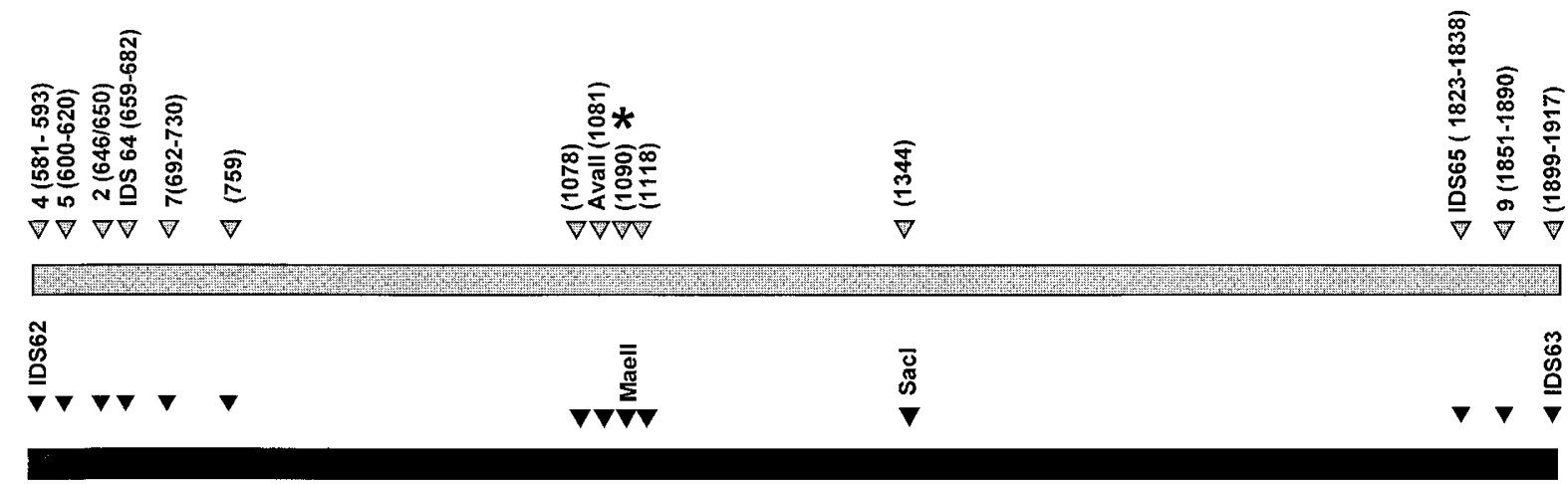

IDS-2, Intron 7

IDS, Intron 7

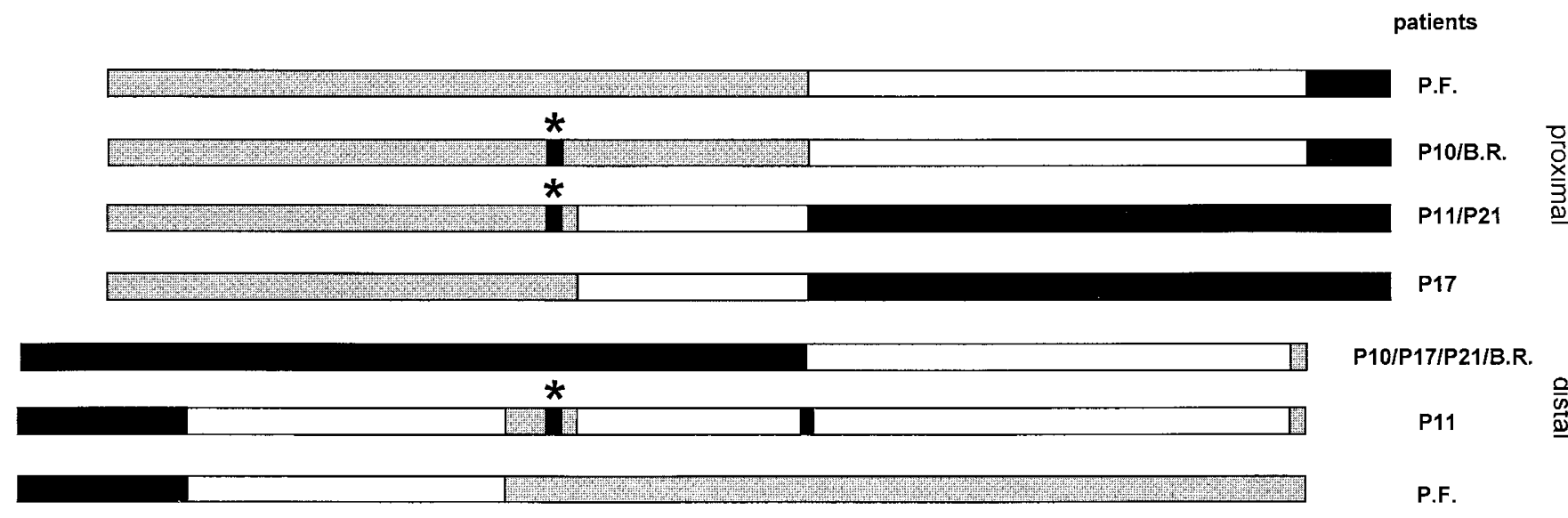

Figure 3 Schematic representation of ID S/ID S-2 inversion junctions. The top panel is similar to Figure 1 except that a smaller area bounded by primers ID S62/IDS63 and ID S64/65 is shown here. Below, the different types of proximal and distal rearranged areas containing the breakpoints are shown. On the right are the initials/numbers of the patients carrying the respective inversion junctions. R egions containing the breakpoints are white. A sterisks mark nucleotide position number 1090 where ID S-2 may harbour the IDS gene-specific nucleotide as polymorphism.

most complex distal breakpoint area with alternating gene and pseudogene sequences.

\section{Discussion}

Mutations of the IDS gene were determined in our laboratory in more than 70 patients from different European countries, with the two largest subgroups originating from Germany and Poland. Whilst about $80 \%$ of them carry point mutations or small deletions/ insertions, ${ }^{6,13,14,16}$ the remaining $20 \%$ have large structural rearrangements. Two out of $44 \mathrm{G}$ erman patients carry an inversion $(4.5 \%)$, another three deletions of the whole gene $(6.8 \%)$, ie $11.3 \%$ in total have gross rearrangements. In contrast, four out of 18 Polish patients have inversions (22\%) and three have partial gene deletions ( $16.6 \%$ ); thus almost $40 \%$ bear large structural aberrations. A s the four Polish patients with inversions originate from a relatively small area in the south-east of the country, a common ancestor was assumed. However, characterisation of the inversion breakpoints strongly suggests that all four gene alterations are of independent origin. It is not clear at present whether the dissimilar frequency of mutation types in these two populations is significant, as the number of Polish patients investigated so far is still small.

Comparison of our data with a recent publication ${ }^{15}$ showed that P17 and P21 had breakpoints identical to two patients (nos V and IV) described in that study. Therefore those patients may be the same as the individuals studied by us. With our results and the information from that paper, inversion breakpoints are now defined for at least 10 unrelated patients with M PS II. A Ithough most of the inversion junctions have different sequences and initial double-strand breaks have probably occurred at different positions, all these mutations are likely to be due to the same molecular 
mechanism since they occurred within the same $1.6 \mathrm{~kb}$ area which is $96 \%$ homologous between intron 7 of IDS and intron 7 of IDS-2. Interestingly, there is no insertion or deletion of nucleotides at the breakpoints and gene conversion is observed in most cases, which can be explained by the double-strand breakage model of recombination. ${ }^{15}$ Remarkably, an experimental model used to investigate mechanisms of mammalian recombination resembles quite well the 'natural' recombination hot spot IDS/IDS-2. In the study by Bollag and Liskay, ${ }_{17}$ two invertedly positioned genes bounded by distinguishable markers and defined by two different mutations were stably introduced into the genome of mouse cells. The authors found that $94 \%$ of the recombination events observed were nonreciprocal, ie conversion events, while 6\% led to inversions (were reciprocal) with or without additional conversions. Indeed, IDS and IDS-2 specific polymorphisms are observed frequently at distinct positions of the pseudogene and functional gene, respectively $\mathrm{y}^{15}$ (and Bunge, S, 1997) unpublished observations), which are suggestive of frequent conversion events. A s there are no differences in the exonic regions of high homology, such conversions have no clinical consequence and remain unnoticed. O ne may also speculate that conversions are responsible for maintaining the high degree of homology between the related sequences. While in the experimental system only about one-third of the inversions showed gene conversions, 'natural' ID S/ID S2 inversions were accompanied by conversions, ie nonreciprocal recombination, in most cases. However, each of the experimental inverted repeats carried only one mutation, ${ }^{17}$ whilst there are more differences between IDS and IDS-2 making detection of conversion more probable.

A ccording to the literature, recombination occurs more frequently in longer stretches of DNA with high degree of homology. ${ }^{18}$ The second $1.3 \mathrm{~kb}$ homologous region of IDS-2 (second half of exon 2 to first half of intron 3) has an even higher homology to the corresponding region of IDS $(98.4 \%)$ than has the intron 7 region. As there is no significant size difference between these two regions, it is surprising that up to now no inversions involving the exon 3 region have been observed. A nother gene on distal Xq involved in human disease due to partial regional duplications is the factor VIII gene. Two inverted copies of a $9.5 \mathrm{~kb}$ region of intron 22 exist about 300 and $400 \mathrm{~kb}$ telomeric to the factor VIII gene. ${ }^{19}$ In about $50 \%$ of all cases with severe haemophilia A, an inversion due to intra- chromosomal recombination between intron 22 and one of the two telomeric copies is found with the more distant repeat being involved four times more often. ${ }^{19}$ A Ithough the size of the homologous regions and the distance between them are quite different when comparing factor VIII and the ID S regions, it seems that in both cases the homologous regions more distant from each other are the preferred sites of recombination events. R ecently, a third example of a regional duplication in Xq28 was described involving two $11.3 \mathrm{~kb}$ inverted repeats with $99 \%$ sequence identity surrounding the emerin and filamin genes. ${ }^{20}$ Recombination between these repeats was found not only to result in a deletion/duplication mutation of a patient with E meryD reifuss muscular dystrophy but also in inversions present on $18 \%$ of normal $X$ chromosomes. ${ }^{21}$

For the above mentioned regions in Xq28 a higher frequency of recombinations closer to the telomere applies, and imperfect pairing of $X$ and $Y$ chromosomes in male meioses may make intrachromosomal recombinations more likely. Indeed, for the factor VIII gene, the prevalence of inversions in male meioses was shown. ${ }^{22}$ In MPS II, evidence for an elevated maleto-female mutation ratio was found but most of the mutations with proven parental origin were point mutations. ${ }^{6}$ Extended investigations will be necessary to determine whether or not inversions and other major rearrangements occur more frequently in male meiosis.

O ne may speculate that the present structure of ID S2 arose during evolution after an inverted duplication of the IDS gene followed by three deletion events, one at the beginning of the gene (exon 1, intron 1, 5' half of exon 2), one towards the end (second half of intron 7 to exon 9), and one internal deletion (2/3 of intron 3 to intron 7 [5' part] including exons 4 to 7). R ecombination events promoted by very small stretches of homology have been described for experimental systems $s^{23}$ and for mutations leading to human disease. ${ }^{24,25}$ The sequence CTGGT occurs once in intron 3 and twice in intron 7. It is likely that the multiple presence of this sequence motif played a role in the stepwise rearrangement of ID S-2 during evolution, as it represents the overlap between the intron 3 and intron 7 homologous regions. The fact that in the three patients analysed here two different types of intragenic deletions result in connecting introns 3 and 7 in the same way they are joined in the pseudogene makes it very likely that the pseudogene was involved in the mutational event. A recombination event is proven by the 
fact that regions of 700 and 900 nucleotides were converted from gene to pseudogene in two patients with deletions. A third patient presented here has an even more complex mutation with an inversion of the $5^{\prime}$ part of IDS and presumably a large deletion between IDS and gene W. Figure 2 shows a model of how a nonallelic intrachromosomal pairing of homologous regions of gene and pseudogene with loop formation in ID S could have resulted in internal deletion or deletion with inversion. In principle, such a recombination could have been intermolecular, ie involve sister chromatids or the homologous $X$ chromosome in female meiosis, but then dissolving with an additional inversion would be difficult to explain. A patient described in the literature ${ }^{26}$ carries a rearrangement related to the mutations of the patients $\mathrm{P} 1, \mathrm{JN}$, and P16. However, as in that patient pseudogene specific homozygosity was found at position +12 in intron 3 where we saw heterozygosity in our cases, these mutations are not identical, although all four recombinations arose probably by the same molecular mechanism.

Certainly the specific genomic constitution that emerges from the growing number of regions with different regional duplications in X q28 is important in explaining nonallelic recombinations leading to $X$-linked diseases. M oreover, naturally occurring intrachromosomal recombinations of the types described in the present study may provide insights into more general mechanisms of crossover events in mammals.

\section{Acknowledgements}

This study was financially supported by the Deutsche Forschungsgemeinschaft (B u 930/2-1).

\section{References}

1 Neufeld E, Muenzer J: The mucopolysaccharidoses. In: Scriver CR, B eaudet AL, Sly WS, Valle D (eds). The $M$ etabolic and Molecular Bases of Inherited Disease. M cG raw-Hill: New Y ork, 1995, 2465-2494.

2 Wilson PJ, M orris CP, A nson D S et al: H unter syndrome: isolation of an iduronate-2-sulfatase cDNA clone and analysis of patient DNA. Proc Natl A cad Sci USA 1990; 87: 8531-8535.

3 Flomen R H, G reen E P, G reen PM , B entley D R, G iannelli $F: D$ etermination of the organisation of coding sequences within the iduronate sulphate sulphatase (ID S) gene. $\mathrm{H} \mathrm{um}$ Mol G enet 1993; 2: 5-10.

4 Wilson PJ, Meaney CA, Hopwood JJ, Morris CP: Sequence of the human iduronate-2-sulfatase (IDS) gene. G enomics 1993; 17: 773-775.
5 H opwood JJ, Bunge S, M orris CP et al: M olecular basis of mucopolysaccharidosis type 1I: mutations in the iduronate-2-sulphatase gene. H um M utat 1993; 2: 435-442.

6 Rathmann $M$, Bunge $S$, Beck $M$, K resse $H$, TylkiSzymanska A, Gal A: Mucopolysaccharidosis type II (H unter syndrome): M utation 'hot spots' in the iduronate2-sulfatase gene. A m J H um G enet 1996; 59: 1202-1209.

7 R athmann $M$, Bunge S, Steglich $C$, Schwinger $E, G$ al A : $E$ vidence for an iduronate-sulfatase pseudogene near the functional $\mathrm{H}$ unter syndrome gene in Xq27.3-q28. Hum G enet 1995; 95: 34-38.

8 Bondeson $M L$, Malmgren $H, D a h l ~ N$, Carlberg BM, Pettersson U : Presence of an ID S-related locus (ID S2) in $\mathrm{Xq28}$ complicates the mutational analysis of $\mathrm{H}$ unter syndrome. E ur J H um G enet 1995; 3: 219-227.

9 Timms KM, Lu F, Shen $Y$ et al: 130 kilobases of DNA sequence reveals two new genes and a regional duplication distal to the human iduronate-2-sulfate sulfatase locus. G enome Res 1995; 5: 71-78.

10 Bondeson $\mathrm{M} \mathrm{L}, \mathrm{D}$ ahl N, M almgren $\mathrm{H}$ et al: Inversion of the IDS gene resulting from recombination with ID S-related sequences is a common cause of the $\mathrm{H}$ unter syndrome. $\mathrm{H}$ um Mol G enet 1995; 4: 615-621.

11 Steen-B ondeson M L, D ahl N, Tönneson T et al: M olecular analysis of patients with $\mathrm{H}$ unter syndrome: implication of a region prone to structural alteration within the IDS gene. Hum M ol Genet 1992; 1: 195-198.

12 Steglich C, Bunge S, H ulsebos T et al: M olecular analysis of patients with mucopolysaccharidosis type II suggests that DXS466 maps within the $\mathrm{H}$ unter gene. $\mathrm{H}$ um $\mathrm{G}$ enet 1993; 92: 179-182.

13 Bunge $S$, Steglich $C, B$ eck $M$ et al: M utation analysis of the iduronate-2-sulfatase gene in patients with mucopolysaccharidosis type II (H unter syndrome). $\mathrm{H}$ um $\mathrm{M}$ ol $\mathrm{G}$ enet 1992; 1: 335-339.

14 Bunge $S$, Steglich C, Zuther C et al: I duronate-2-sulfatase gene mutations in 16 patients with mucopolysaccharidosis type II (Hunter syndrome). Hum Mol Genet 1993; 2: 1871-1875.

15 Lagerstedt K, Karsten SL, Carlberg B-M et al: Doublestrand breaks may initiate the inversion mutation causing the $\mathrm{H}$ unter syndrome. $\mathrm{H}$ um M ol G enet 1997; 6: 627-633.

16 Popowska E, Rathmann M, Tylki-Szymanska A et al: Mutations of the iduronate-2-sulfatase gene in 12 Polish patients with mucopolysaccharidosis type II (Hunter syndrome). H um M utat 1995; 5: 97-100.

17 Bollag RJ, Liskay RM : Conservative intrachromosomal recombination between inverted repeats in mouse cells: association between reciprocal exchange and gene conversion. G enetics 1988; 119: 161-169.

18 M etzenberg A B, Wurzer G, H uismann THJ, Smithies O : $\mathrm{H}$ omology requirements for unequal crossing over in humans. G enetics 1991; 128: 143- 161.

19 Naylor JA, Buck D, G reen P, Williamson H, Bentley D, $G$ ianelli $F$ : Investigation of the factor VIII intron 22 repeated region (int22h) and the associated inversion junctions. $\mathrm{H}$ um $\mathrm{M}$ ol $\mathrm{G}$ enet 1995; 4: 1217-1224.

20 Chen $E Y$, Zollo $M$, Mazzarella $R$ et al: Long-range sequence analysis in $X$ q28: thirteen known and six candidate genes in $219.4 \mathrm{~kb}$ of high G C DNA between the $\mathrm{RCP} / \mathrm{GCP}$ and G 6PD loci. Hum Mol Genet 1996; 5: 659-668. 
21 Small K, Iber J, Warren ST: Emerin deletion reveals a common $\mathrm{X}$-chromosome inversion mediated by inverted repeats. Nat G enet 1997; 16: 96-99.

22 R ossiter J P, Y oung M, K imbberland M L et al: Factor V III gene inversions causing severe hemophilia $A$ originate almost exclusively in male germ cells. $\mathrm{Hum} \mathrm{Mol} \mathrm{G} \mathrm{enet}$ 1994; 3: 1035-1039.

23 Mezard C, Nicolas A: Homologous, homeologous, and illegitimate repair of double-strand breaks during transformation of a wild-type strain and a rad52 mutant strain of Saccharomyces cerevisiae. Mol Cell Biol 1994; 14: 1278-1292.
24 Ketterling RP, Ricke DO, Wurster MW, Sommer SS: Deletions with inversions: Report of a mutation and review of the literature. $\mathrm{H}$ um M utat 1993; 2: 53-57.

25 Lazaro $C$, Gaona A, Lynch $M$, K ruyer $H$, Ravella $A$, E stivil $X$ : M olecular characterization of the breakpoints of a 12-kb deletion in the NF1 gene in a family showing germ-line mosaicism. Am J Hum Genet 1995; 57: 1044-1049.

26 Birot A - M , B outon O, Froissart R, M aire I, B ozon D : ID S gene-pseudogene exchange responsible for an intragenic deletion in a $\mathrm{H}$ unter patient. $\mathrm{H}$ um M utat 1996; 8: 44-50. 